\author{
L. Grumeza, V. Bârcă
}

\title{
GLASS BEADS DISCOVERED IN THE SARMATIAN CEMETERIES FROM SOUTH-WESTERN ROMANIA
}

This article analyses the glass beads discovered in the Sarmatian cemeteries from south-western Romania. Beads are the most numerous objects identified among grave goods (over 14000 specimens), being present in 43 cemeteries dated between the $2^{\text {nd }}-4^{\text {th }}$ century $A D$. Typologically, we identified 9 main types of monochrome beads and 8 polychrome (each with variations and different colours). Most often, beads were sewn onto apparel, being highly important for discussions concerning the fashion of the time, trading relations and Roman-Barbarian contacts.

Keywords: glass beads, Sarmatians, cemeteries, Roman-provincial workshops, Western Plain of Romania, Banat region.

Introduction. Beads were broadly used over the course of time on vast spreads during the Antiquity, which explains the continuation of a large number of types across large time spans. As an archaeological material class, they are a rather significant historical source, being artefacts offering a large scale picture of the trading relations, crafts' development, aesthetic tastes and other aspects of the ancient communities' lives.

Beads were mainly worn in strings around the neck, precisely because of this, being chiefly discovered on the chest and around the neck of the deceased. Nonetheless, most often in the Sarmatian world, they are discovered by the wrist or ankle of the dead. Certain bead types were sewn onto apparel, especially by the collar, cuffs and hems, however also in the waist area and on trousers. There are cases when sword belts were also beaded, in this cases beads lying in the handle and blade area. Similarly to other adornment

(c) L. GRUMEZA, V. BÂRCĂ, 2020 classes, beads most certainly fulfilled a decorative and cultic-magical role. They provide an image of the aesthetic choices and ideas existing in the Sarmatian world, and not only. This likely explains why most often they are discovered together with various pendants and amulets. Special attention was granted in Antiquity, and not only, to beads made of semiprecious stones. By their aesthetic and physical qualities (colour, hardness, gloss, strength, shine, etc.) were believed to carry certain out of the ordinary qualities.

In the first centuries $\mathrm{AD}$, beads were frequent in the Sarmatian environment, while according to their material, shape and decorative patterns, they are similar to those of the same period from a vast area and different cultural settings. All of these furthermore evidence that beads count among the most spread adornments, being at high demand as early as most ancient times. The Sarmatians are no exception, since beads are ones of most numerous and frequently used jewellery pieces.

Bead making required high craftsmanship, which, as previously noted (Skripkin 1990, p. 75), made impossible their production in the nomad environment, to which the Sarmatians also belonged. For this reason, most beads reached them by trade with the Roman empire and the centres from the north of the Black Sea. Still, some coarsely made beads in bone, chalk or various stones might have been crafted in Sarmatian environment.

In the Sarmatian graves of the Great Hungarian Plain beads are quite frequent, in some cases their numbers reaching hundreds or thousands. On the territory of Banat, we may mention for instance grave 24 at Pančevo-Vojlovica, where 
2215 beads ${ }^{1}$ were discovered (Batistić-Popadić 1984-1985, p. 62). Nevertheless, their number differs from one burial ground to another, according to the peculiarities of each site, distance from the limes, quantity of Roman imports within the burials, resources available to respective communities, the chronological period to which the bur$\mathrm{ial} /$ cemetery belongs to or the number of female graves in each cemetery. Circumstances are similar in the Sarmatian funerary complexes from plain territories located northward (the Crişana region) and southward (the Banat region) the Lower Mureş river (Grumeza 2014, p. 93-104 with complete bibliography).

We shall discuss below the glass beads discovered in the cemeteries ascribed to the Sarmatians, especially Foeni-Cimitirul Ortodox, Giarmata Sit 10 (Timiş county) and Hunedoara Timişană (Arad county; fig. 1). These not very large three cemeteries from south-western Romania were investigated in the last years via rescue excavations, yielding a total number of 62 burials dated to the period between the end of the Marcomannic wars and the third quarter of the $3^{\text {rd }}$ century $\mathrm{AD}$ (stages $\mathrm{C} 1 \mathrm{a}-\mathrm{C} 1 \mathrm{~b} / \mathrm{C} 2$ in the Central-European chronology).

The Sarmatian cemeteries from Foeni Cimitirul Ortodox, Hunedoara Timişană and Giarmata - Sit 10. General data. Between 1991 - 2002, the Museum of Banat in Timişoara and the Institute of Archaeology and Art History of Cluj-Napoca carried out systematic archaeological excavations in Foeni (Timiş county), site Cimitirul ortodox, the investigated assemblages being mainly prehistoric. In the 1991-1993, 1996-1998 and 2001-2002 excavation campaigns 18 Sarmatian graves were also discovered, definitely part of a larger cemetery mostly destroyed by the current orthodox cemetery. Based on the preserved funerary furniture, the group of graves at Foeni may be dated to the end of the $2^{\text {nd }}-$ mid / third quarter of the $3^{\text {rd }}$ century $\mathrm{AD}$ (Tănase, Mare 2000; Grumeza 2011; Grumeza 2014, p. 179-185, Bârcă, Grumeza 2014, p. 163, 164). Half of the skeletons are oriented northsouth (graves $4-8,11,12,16$ ), while the other half with the head southwards (graves $1-3,10$, $14,15,17,18)$. Only one grave was located on the west - north-west axis, another orientation cannot be specified (due to the grave's looting). Unfortunately, it is impossible to say which was the cemetery's layout (i. e. the presence of ditches, graves' grouping, etc.), because the Sarmatian cemetery was superimposed (and partially destroyed) by the contemporary orthodox graveyard.

1. The number of beads is impressive, if we consider that in the 3 bead officinae from Tibiscum, only 10158 intact specimens were recorded over the entire period of the 2 nd -4 th centuries $\mathrm{AD}$ (Benea 2008, p. 135).

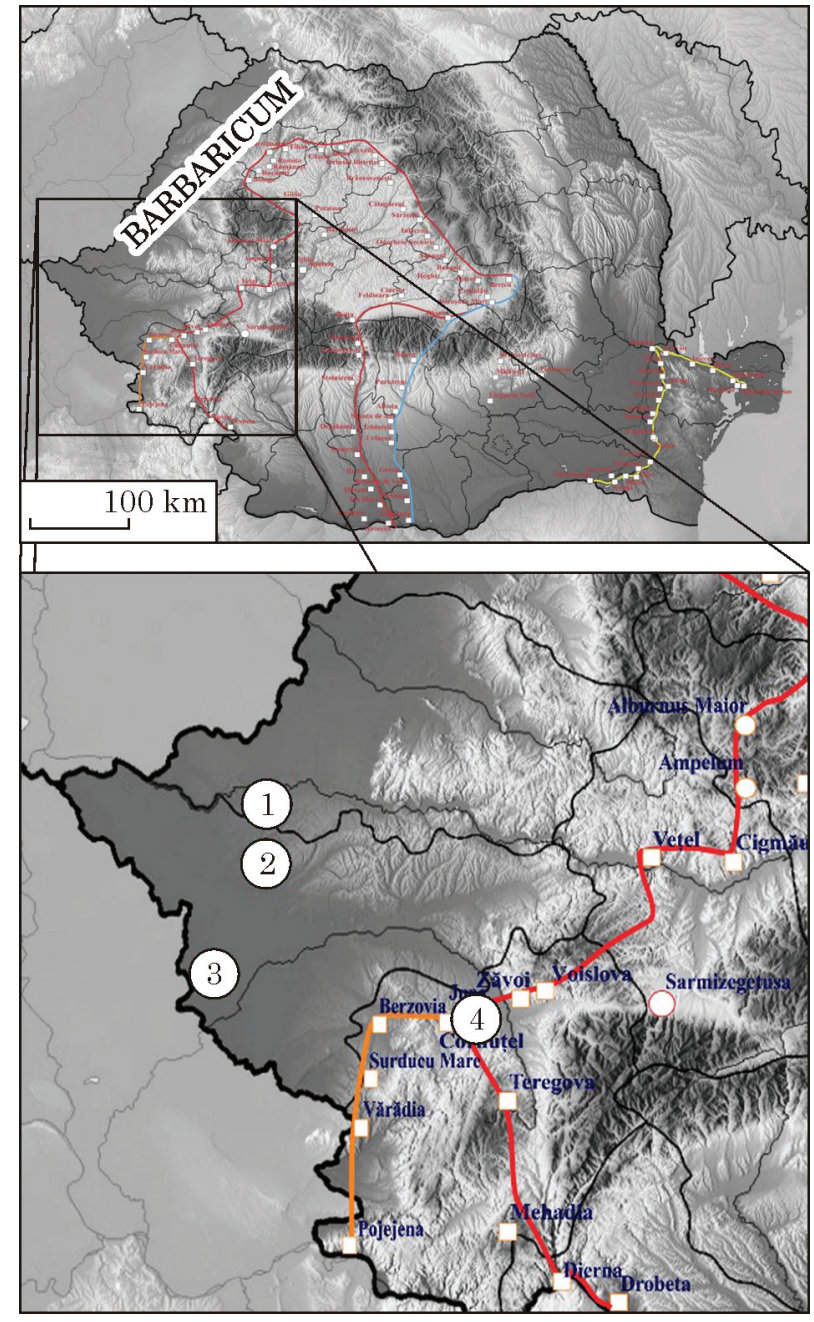

Fig. 1. The research area with the main Sarmatian cemeteries mention within the text: 1 - Hunedoara Timişană; 2 - Giarmata - Sit 10; 3 - Foeni-Cimitirul Ortodox; 4 - Tibiscum, Roman beads workshop on the Dacian limes (limes Dacicus and Barbaricum after www.limesromania.ro, with additions)

In the summer of 2010, the rescue archaeological excavations prior the construction of the Arad-Timişoara Highway, respectively the AradSeceani section, investigated several archaeological sites and features, among which also site $\mathrm{BO}_{-}$ 7-BO_8, located within the range of Hunedoara Timişană village, Şagu commune (Arad county; Bârcă et al. 2011, p. 187-192; Bârcă 2014, p. 12-14). The investigations yielded 17 inhumations to which add the pieces from a grave destroyed by the construction of an early medieval house. The discovered graves represent a small settlement-related cemetery whose nucleus lay west the highway route (Bârcă 2014a, p. 14). The graves' layout indicates that eastward and westward, outside the investigated limits, there existed other graves as well. The excavations performed in the southern side of the excavated perimeter investigated features of the Sarmatian settlement dated to the $3^{\text {rd }}-4^{\text {th }}$ century $\mathrm{AD}$ and a few features from the early medieval pe- 
riod (Bârcă et al. 2011, p. 187-192; Bârcă 2014a, p. 14). Except for grave 3, all the other had a rectangular gravepit with rounded corners, while in 14 cases the deceased were buried with head northwards, north-north-westwards and northnorth-eastwards (Bârcă 2014, p. 73, 80) ${ }^{1}$. The predominant northern orientation of the graves from Hunedoara Timişană confirms, beside other previous or more recent finds, the entry of certain Sarmatian groups (the Roxolani) in the Great Hungarian Plain in the period after the Marcomannic wars (Bârcă 2014, p. 141). Chronologically, the grave groups from Hunedoara Timişană date to the interval comprised between the end of the $2^{\text {nd }}$ century and the third quarter of the $3^{\text {rd }}$ century AD (Bârcă 2014a; 2014b, p. 29; 2016, p. 253, 254).

From the route of the same Arad-Timişoara motorway, more precisely from Site 10 located within the boundary of Giarmata village (Timiş county), comes another Sarmatian cemetery, where 32 graves were identified, 26 being dated between last quarter of the $2^{\text {nd }}$ - third quarter of the $3^{\text {rd }}$ century AD (Grumeza 2014, p. 185-198; Bârcă, Grumeza 2014, p. 161-163; Bârcă 2014, p. 72). Within the same site were discovered and researched many prehistoric archaeological assemblages and a late Sarmatian settlement contemporary with another small cemetery. In this paper we shall refer to the graves dated to the last quarter of the $2^{\text {nd }}$ - third quarter of the $3^{\text {rd }}$ century AD. These features were placed as four groups, with distances from a few tens of meters to almost one hundred meter in-between. The "grave nests» were delimited one from the other by long, almost parallel ditches. They do not surround a central grave (or several), but delimited certain grave groups. Very likely, we are dealing with a division of the funerary space upon social or ethnic criteria. The graves are oriented mainly on the south / south-west/ south-east axis. Just in

1. Placing the deceased within graves with head northwards is uncommon to the Sarmatian environment of the Great Hungarian Plain, where over four centuries, the southern orientation dominated. In the area south the Lower Mureş river, the northern oriented graves emerge sometime by the end of the 2nd century - early 3rd century AD, being frequent in late date cemeteries, mainly in the southern part of the region. A somewhat larger clustering is yet noted north the Lower Mureş river, in the Criş-Mureş-Tisza area and also along the northern limits of the Sarmatian inhabitancy (Kulcsár 1998, p. 16-20, 93, 109; Bârcă 2014, p. 8083; Grumeza 2014, p. 49-51). The emergence of the northern orientation in the Great Hungarian Plain beside other funerary customs and elements related to dress and costume is indicative of the entry of new Sarmatian groups from the north-west Pontic area after the Marcomannic wars (see further Párducz 1960, p. 74; Kulcsár 1998, p. 93, 109; Simonenko 1993, p. 63; 2001, p. 117, 122; Bârcă 2014, p. 82, 83, 141). two graves (G. 7 and 25) the deceased are placed with the head towards north / north-east.

The results of the archaeological research carried out at Foeni, Hunedoara Timişană and Giarmata, supply a multitude of data regarding the interaction of the Sarmatians with the Roman and Germanic worlds and represent, beside other recent finds, proof that the Sarmatians settled the territory south the Lower Mureş river after the Marcomannic wars. Also, it is very likely that the deceased buried with the head northwards from cemeteries on the territory of Banat ${ }^{2}$, were Sarmatian, arriving in this region of the northwest Pontic area or their descendants.

The finds at Foeni, Hunedoara Timişană and Giarmata, together with the other Sarmatian cemeteries and settlements discovered over the last two decades in territories west of the province of Dacia indicate that their settlement in these regions was significant only after the Marcomannic wars, when certain Sarmatian groups massively entered these territories, likely with Roman agreement and under their careful control. It is further certain that for between years $20-70 / 80$ of the $2^{\text {nd }}$ century $A D$, there was no Sarmatian inhabitancy in the territory south the Lower Mureş. Such archaeological facts show that territories around the western and south-western borders of the province of Dacia were under efficient Roman control. The numerous Sarmatian settlements and cemeteries discovered in the plain part of the territory south the Lower Mureş river indicate the area was not incorporated, as argued until recently in the Romanian historiography (Daicoviciu 1942, p. 103; Benea 1996, p. 114), in the province territory, but lay outside its south-western border located not far from the last westward forts along the Lederata-BerzobisTibiscum road. Concurrently, it is certain that this territory, under Roman control, lay though extra provinciam.

Glass beads typology (tables 1 and 2; fig. 2$5)$. Beads are the most numerous grave goods. They emerge in 43 cemeteries ascribed to the Sarmatians and researched in western Romania (18 in Arad county and 25 in Timiş county). These cemeteries yielded over 14000 beads ${ }^{3}$. Amongst, are notewor-

2. For the graves in Banat, with heads of the deceased oriented northwards see Grumeza 2014, p. 49-51.

3. For instance, for the Arad county, we approximate a total number of 6000 specimens. Even if we identified, documented and recorded in the data base a number of 3727 beads (and other hundreds of fragments), ca. a third of the graves discovered in the Arad county - especially those identified in the 20th century - either have no specified number of total beads found or the materials were lost; see for instance, the case of grave 9 at Zădăreni: «Scattered around the skeleton there were discovered a multitude of beads of various colours in clay, shells, glass etc. forming a total length of 4 meters" (archive E. Dörner, Arad Museum Complex; beads are currently lost). 
Table 1. Monochrome beads: typology and general observations (see fig. 2, 3)

\begin{tabular}{|c|c|c|c|c|c|c|}
\hline \multirow{2}{*}{ Group } & \multirow{2}{*}{ Form } & \multicolumn{5}{|c|}{ Variation } \\
\hline & & $\mathrm{A}$ & B & $\mathrm{C}$ & $\mathrm{D}$ & $\mathrm{E}$ \\
\hline $\mathrm{I}$ & Globular & $\begin{array}{l}\text { Very small sizes; always } \\
\text { beaded on apparel }\end{array}$ & $\begin{array}{l}\text { The most common } \\
\text { beads; of a wide } \\
\text { chromatic range }\end{array}$ & $\begin{array}{l}\text { Similar to B, } \\
\text { slightly flattened }\end{array}$ & $\begin{array}{l}\text { Melon-shaped; } \\
\text { very rare varia- } \\
\text { tions }\end{array}$ & - \\
\hline II & Biconical & $\begin{array}{l}\text { Large sizes; only white in } \\
\text { colour }\end{array}$ & Most in group II & $\begin{array}{l}\text { Very rare; only } \\
\text { black }\end{array}$ & - & - \\
\hline III & Cylindrical & $\begin{array}{l}\text { Large sizes, alike B; only } \\
\text { white in colour }\end{array}$ & Most in group III & $\begin{array}{l}\text { Pear-shaped; } \\
\text { very rare varia- } \\
\text { tions }\end{array}$ & $\begin{array}{l}\text { Very rare varia- } \\
\text { tions; only red in } \\
\text { colour }\end{array}$ & - \\
\hline IV & Rectangular & Smaller sizes than B & $\begin{array}{l}\text { Most in group IV; } \\
\text { of a wide chro- } \\
\text { matic range }\end{array}$ & \begin{tabular}{|l|} 
Elongated, \\
with hexagonal \\
profile; very rare \\
variations; only \\
dark blue
\end{tabular} & $\begin{array}{l}\text { Of hexagonal } \\
\text { profile }\end{array}$ & $\begin{array}{l}\text { Of flattened } \\
\text { hexagonal } \\
\text { profile; of a } \\
\text { wide chro- } \\
\text { matic range }\end{array}$ \\
\hline $\mathrm{V}$ & Polygonal & $\begin{array}{l}\text { Numerous; of a large chro- } \\
\text { matic variety, predomi- } \\
\text { nate though purple-blue } \\
\text { and cherry hues (imitat- } \\
\text { ing carnelian) }\end{array}$ & \begin{tabular}{|l} 
Of a wide chro- \\
matic range, yet \\
specific to only cer- \\
tain cemeteries
\end{tabular} & - & - & - \\
\hline VI & Biconical & $\begin{array}{l}\text { Dark-blue beads dominate } \\
\text { in a proportion of } 90 \%\end{array}$ & - & - & - & - \\
\hline VII & Sandwich & $\begin{array}{l}\text { Small sized; covered with } \\
\text { a golden leaf }\end{array}$ & $\begin{array}{l}\text { Very rare; covered } \\
\text { with a golden leaf }\end{array}$ & Rare variation & $\begin{array}{l}\text { Small sized; only } \\
\text { red and blue in col- } \\
\text { our; rare variation }\end{array}$ & - \\
\hline VIII & Circular & $\begin{array}{l}\text { Of a great chromatic } \\
\text { variety, yet specific to only } \\
\text { certain cemeteries }\end{array}$ & - & - & - & - \\
\hline IX & Irregular & $\begin{array}{l}\text { Rare, recorded in only one } \\
\text { burial ground (Şofronea) }\end{array}$ & - & - & - & - \\
\hline
\end{tabular}

Table 2. Polychrome beads: typology and general observations (see fig. 4)

\begin{tabular}{|c|c|c|c|c|}
\hline \multirow{2}{*}{ Group } & \multicolumn{4}{|c|}{ Variation } \\
\hline & A & $\mathrm{B}$ & $\mathrm{C}$ & $\mathrm{D}$ \\
\hline $\mathrm{I}$ & \multicolumn{2}{|c|}{$\begin{array}{l}\text { Rare items, often central pieces in necklaces or used as } \\
\text { knobs / buttons }\end{array}$} & - & - \\
\hline II & \multicolumn{3}{|c|}{ All variations have complex decorations; each bead is unique in this type } & $\begin{array}{l}\text { Singular item, recorded in a } \\
\text { single grave (Sânnicolau Mare) }\end{array}$ \\
\hline III & $\begin{array}{l}\text { Singular item, recorded in a single } \\
\text { grave; with the role of obolus (Arad- } \\
\text { Barieră) }\end{array}$ & - & - & - \\
\hline IV & $\begin{array}{l}\text { Most found polychrome bead types; } \\
\text { most often beaded on clothing, to- } \\
\text { gether with other beads }\end{array}$ & $\begin{array}{l}\text { Singular item, re- } \\
\text { corded in a single } \\
\text { grave (Sânnicolau } \\
\text { Mare) }\end{array}$ & - & - \\
\hline $\mathrm{V}$ & $\begin{array}{l}\text { Recorded in a single cemetery (Hune- } \\
\text { doara Timişană) }\end{array}$ & - & - & - \\
\hline VI & \multicolumn{3}{|c|}{$\begin{array}{l}\text { This group and variations are recorded only in the Foeni cemetery; worn } \\
\text { mainly by the hand (as bead bracelets) }\end{array}$} & - \\
\hline VII & $\begin{array}{l}\text { Recorded in a single cemetery (Foeni); } \\
\text { beaded on apparel }\end{array}$ & - & - & - \\
\hline VIII & $\begin{array}{l}\text { Singular item, recorded in a single } \\
\text { grave (Moravița) }\end{array}$ & - & - & - \\
\hline
\end{tabular}




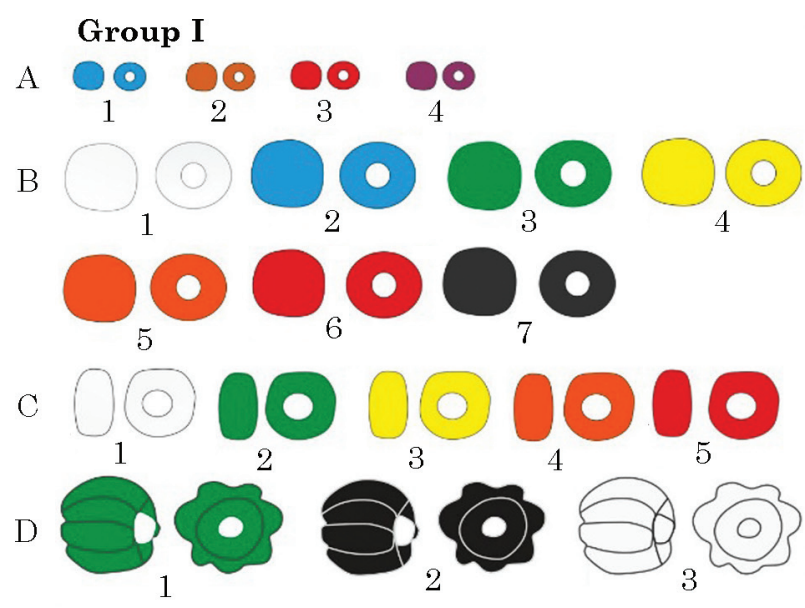

Group II

A

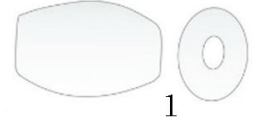

B

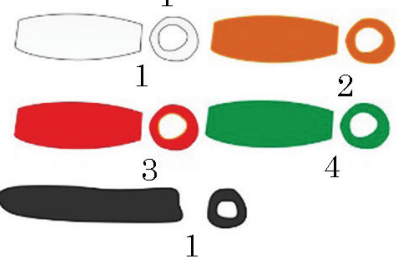

Group III

A

B

C

D
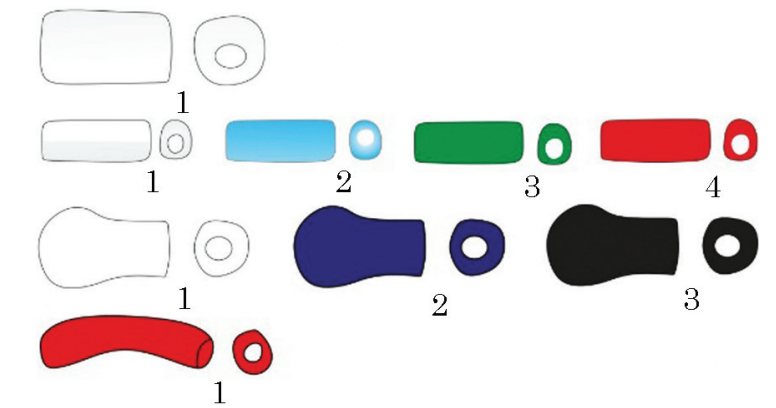

Group IV

A

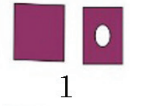

B
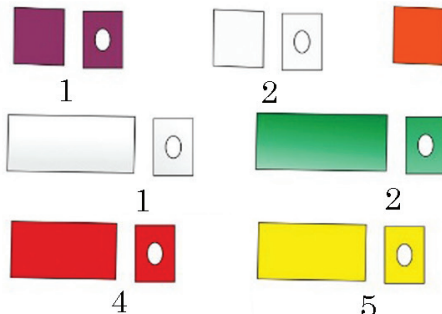

C

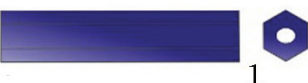

Fig. 2. Types of monochrome beads from Arad and Timiş counties (after Grumeza 2019, with additions)

thy Foeni-Cimitirul Ortodox with 1594 examples (Grumeza 2011, p. 184), Giarmata - Sit 10, with 2204 examples (Grumeza 2014, p. 185-198) ${ }^{1}$ and Hunedoara Timişană with 1396 (Grumeza, Rumegă-Irimuş, Barcă 2014, p. 240; Bârcă 2014,

1. Originally, only 1241 examples were published (Grumeza 2014, p. 185-198). Recently, we identified other 963 specimens in the National Museum of Banat Timişoara, coming from grave 30 , unpublished.

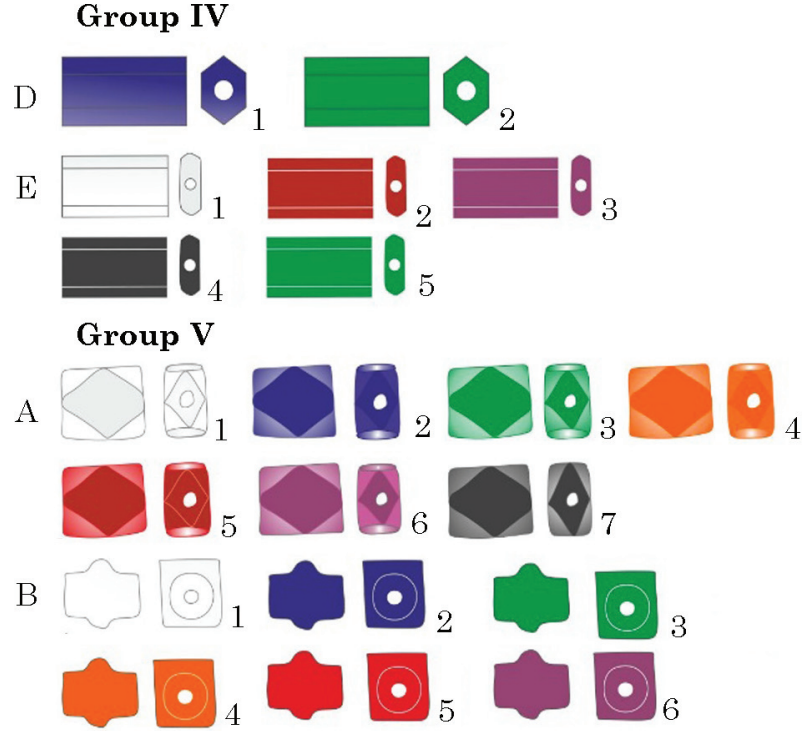

Group VI

$\mathrm{A} \bigcirc \bigcirc \mathrm{O}_{2} \bigcirc 0_{3} \bigcirc 0_{4} \bigcirc 0_{5}$

Group VII

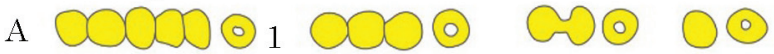

$\mathrm{B}: \because \bigcirc-\mathrm{O}_{1}$

$\mathrm{C} \cap \bigcirc \mathrm{O}_{2} \mathrm{OO}_{3} \mathrm{OOO}$

$\mathrm{D} \bigcirc \odot_{1} \bigcirc \otimes_{2}$

\section{Group VIII}
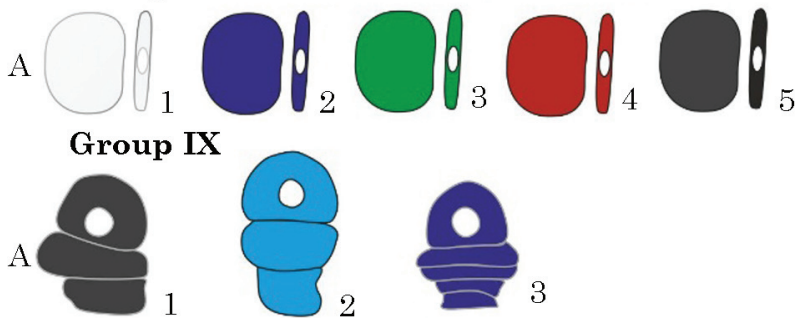

Fig. 3. Types of monochrome beads from Arad and Timiş counties (after Grumeza 2019 with additions)

p. $148-161)^{2}$. According to their raw material, the majority of beads are glass made (in a proportion of $70-90 \%$, depending on each cemetery). For instance, in the Hunedoara Timişană cemetery, $73 \%$ of the beads were glass made (mainly opaque), followed by beads made of a highly friable rock or limestone (9\%) and chalcedony (10\%). Amber beads represent a percentage of $8 \%$ in the analysed graves (fig. 5). Similar statistics are recorded in the Foeni-Cimitirul Ortodox cemetery (92\% glass beads) or Giarmata — Sit 10 (73 \% glass beads).

2. To these add other bead fragments documented in all mentioned cemeteries. Such fragmentation is mostly due to grave looting. For better preserved beads see the fig. $9-11$. 

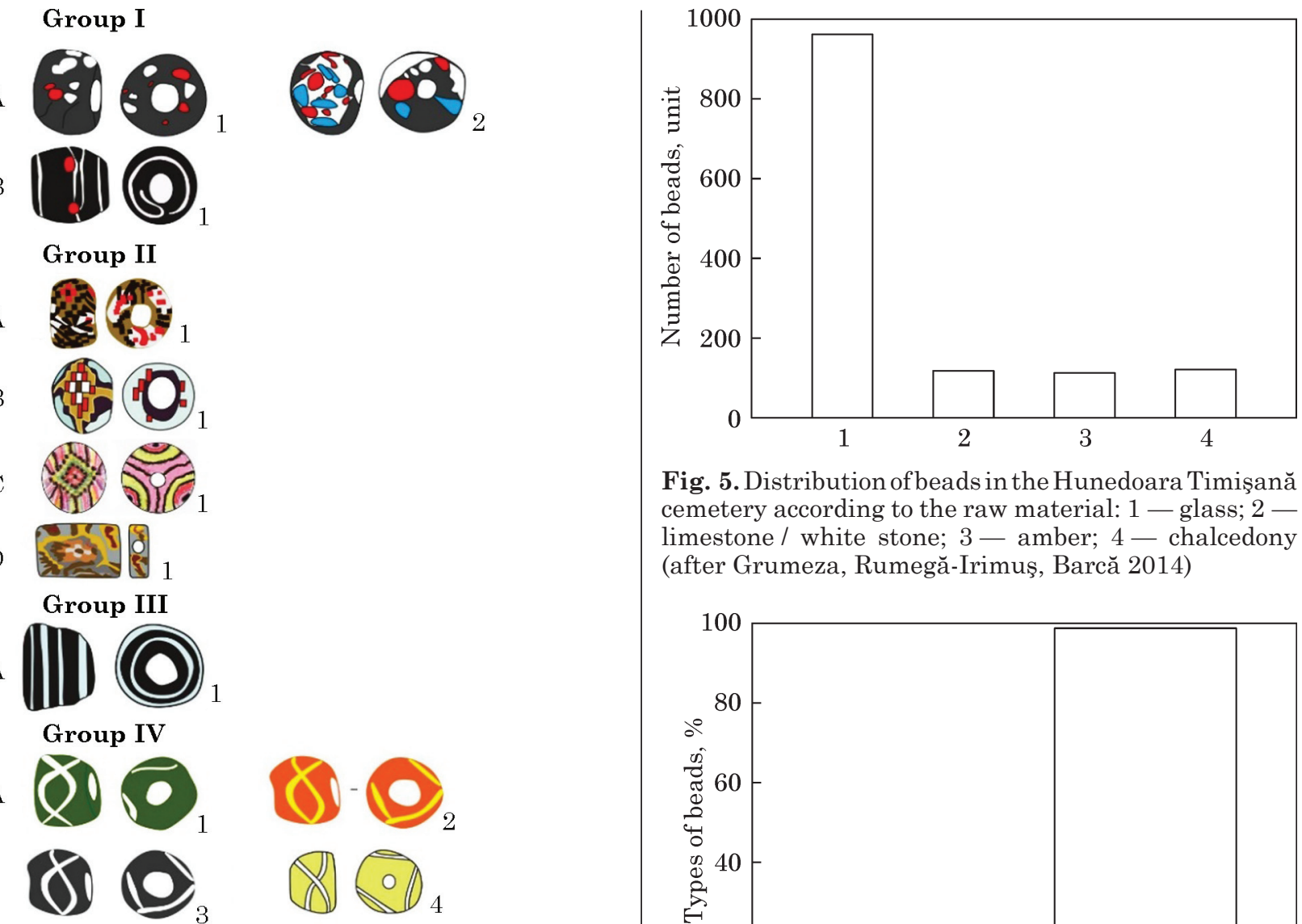

Fig. 5. Distribution of beads in the Hunedoara Timişană cemetery according to the raw material: 1 - glass; $2-$ limestone / white stone; 3 - amber; 4 - chalcedony (after Grumeza, Rumegă-Irimuş, Barcă 2014)

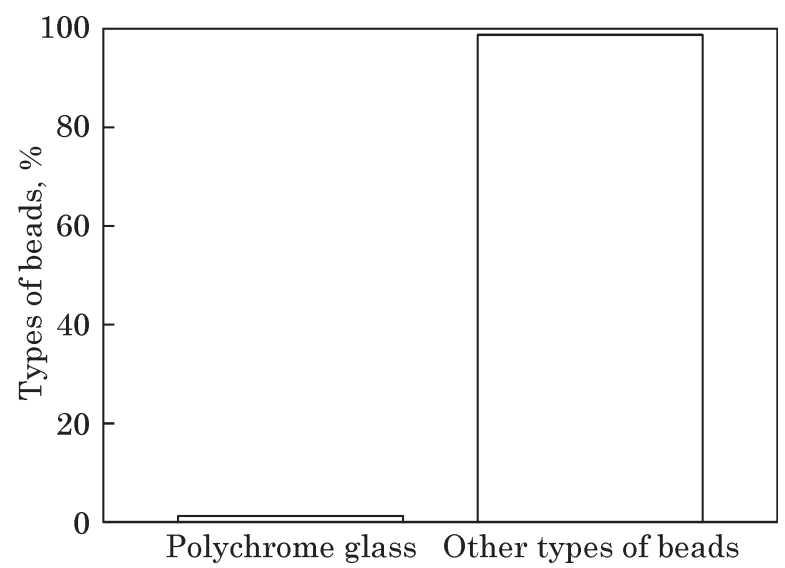

Fig. 6. Distribution of beads in Foeni-Cimitirul Orthodox (1574 versus 20 beads)

kseeva 1975; 1978; 1982). Unfortunately, these typologies may not be adopted in our case, since beads discovered in Sarmatian funerary sites and features from the Great Hungarian Plain (and implicitly today's western Romania) are typological series different than those from the centre, north and east of Europe. Furthermore, the workshops making and then distributing the beads here are known. Therefore, we drafted (Grumeza 2019, pl. 22-25) our own typology, adapted to the realities of the area (fig. 2-4).

In the case of monochrome glass fabric beads we identified nine main types, each with variations and different colours (fig. 2, 3). These types were exhaustively discussed in various studies (Grumeza 2013, p. 245-260; 2014, p. 93-99; Grumeza, Rumegă-Irimuş, Barcă 2014, p. 120-127). We wish to draw a few additional notes and conclusions subsequent to the comprehensive analysis of all types documented in the Sarmatian graves from the area south of the Lower Mureş river.

Multicolour glass beads are much rarer, yet of various shapes: globular, biconical or rectangular. We identified eight main groups with 23 variations, all of a wide chromatic and decorative vari- 

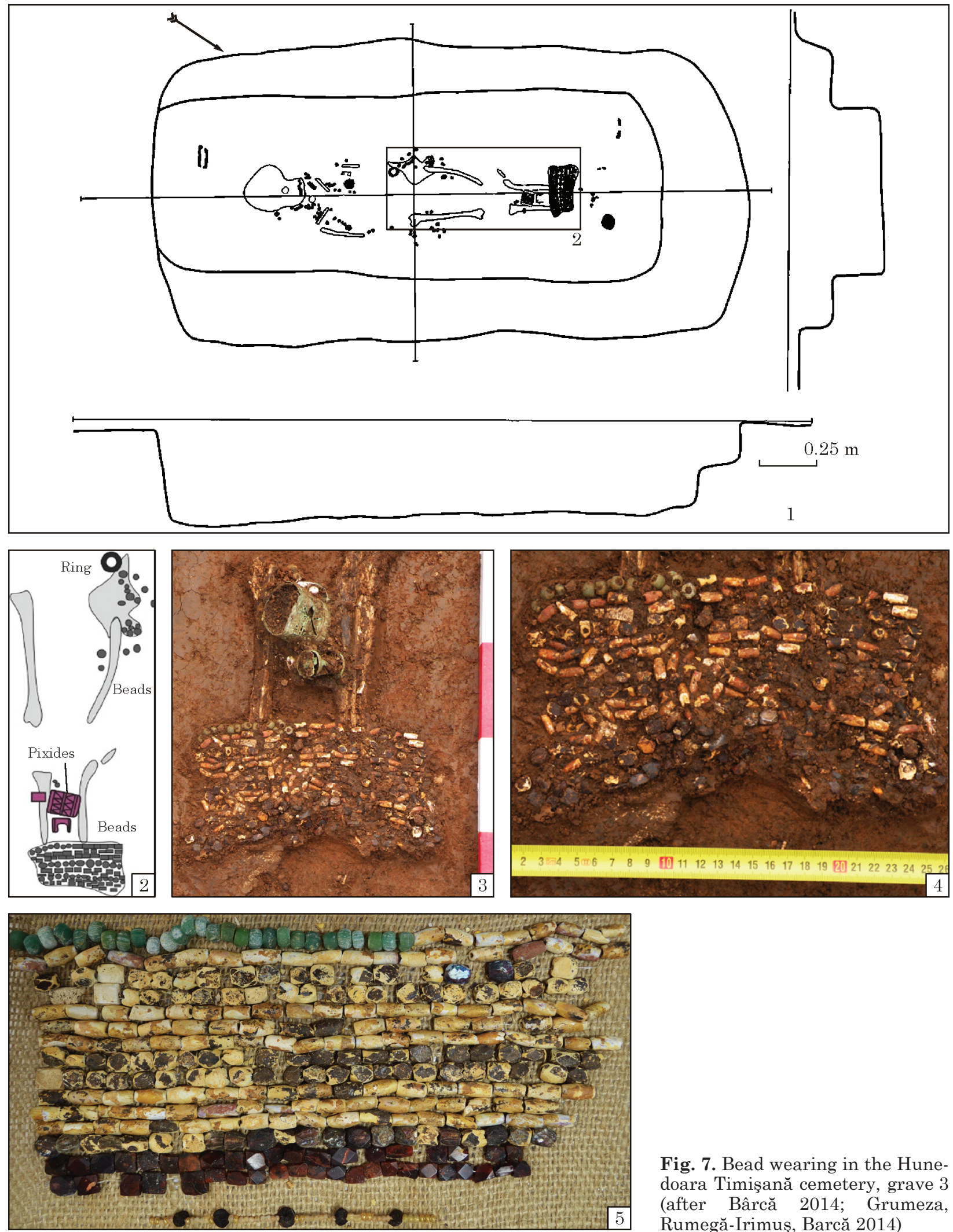

Fig. 7. Bead wearing in the Hunedoara Timişană cemetery, grave 3 (after Bârcă 2014; Grumeza, Rumegă-Irimuş, Barcă 2014)

ety (with geometric, vegetal, floral, etc. patterns). All specimens are larger than monochrome glass beads (up to $2.8 \mathrm{~cm}$ in diameter). Polychrome beads were documented only in 17 graves (from eight cemeteries), the majority in the previously mentioned three sites: Hunedoara Timişană (12 beads), Giarmata (3 beads) and Foeni-Cimi- tirul Ortodox (20 beads). The Foeni cemetery is noteworthy, with most polychrome beads, still less than $1 \%$ of total beads (fig. 6).

These finds were discussed in other papers (Grumeza 2018, p. 193-211; 2020). We wish to make a few additional notes and conclusions, subsequent to the comprehensive analysis of all 

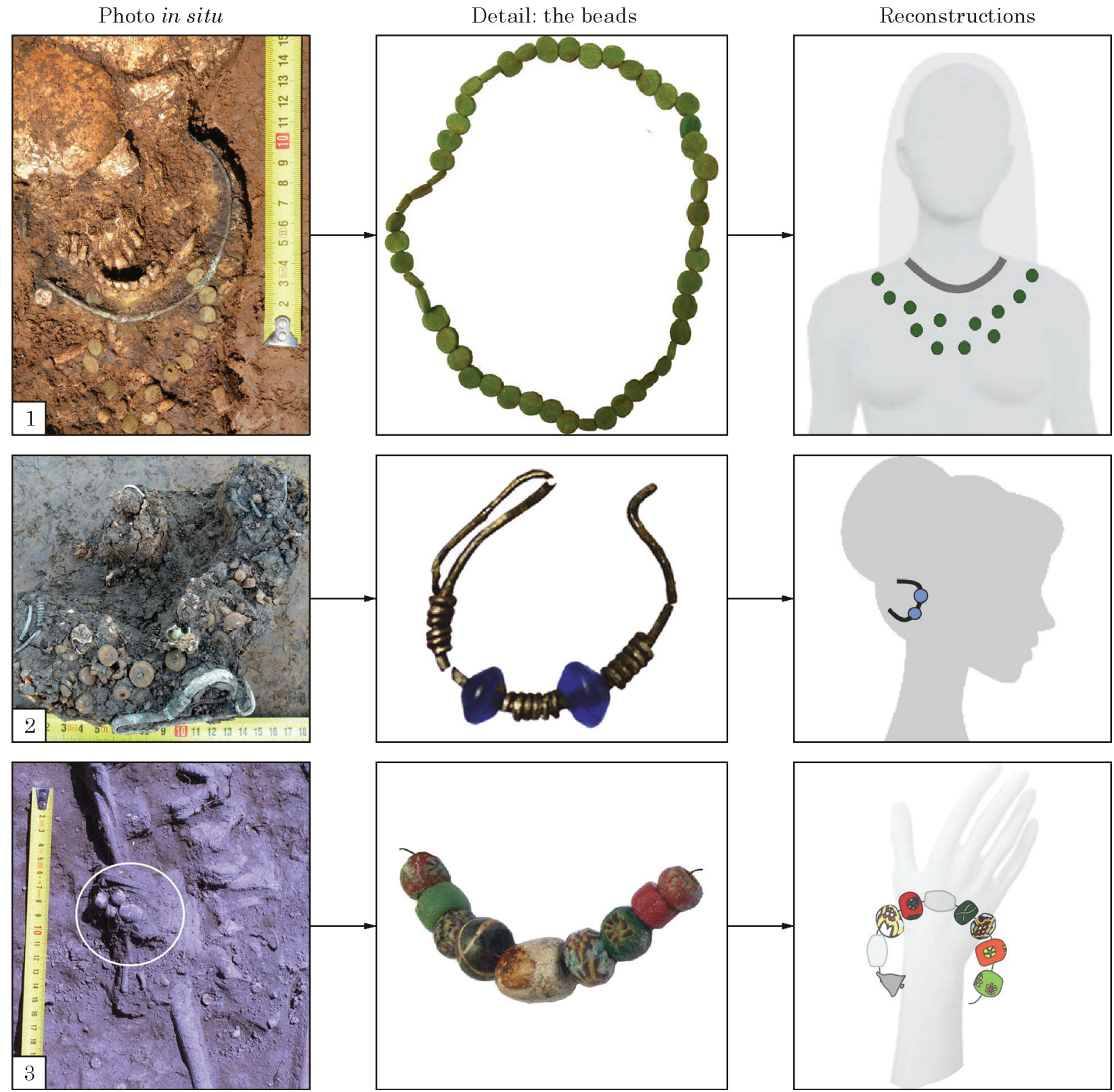

Fig. 8. Rare finds of bead wearing: 1, 2 - Hunedoara Timişană, graves 7 and 14 (after Barcă 2014a); 3 - FoeniCimitirul Ortodox, grave 14 (after Grumeza 2013)

types documented in the Sarmatian graves from Banat and Crişana areas.

The small number of polychrome beads may be explained by the fact they were made via a complicated technology. The raw material consisted of variously coloured dull glass (black, red, green, blue), while the secondary materials were glass stripes also differently coloured, applied on the vitreous mass. In group I, dots were made by a sharp tool (Benea 2004, p. 202). Another production technique was used in the case of group II, whereby by the beginning of bead making, the glass stripes were melted into a basic colour (Benea 2004, p. 203). In the case of florally decorated beads (Group VI), the millefiori technique was used.

Except for Gr. VII, all the other types of polychrome glass beads were produced on the western border of Dacia, in Tibiscum workshops, during the $2^{\text {nd }}-$ early $4^{\text {th }}$ century $\mathrm{AD}$. The functioning of these officinae may be connected to communities of craftsmen, who came from the Syrian-Palestinian-African regions following the establishment of military units in this particular area: cohors I Sagittariorum and numerus Palmyrenorum Tibiscensium (Benea 2004, p. 267). Physical-chemical analyses have shown that it was mainly the Syro-Palestinian workshops that supplied the imperial market with raw glass (Antonaras 2017, p. 6-8, with further bibliography).

The fashion in the graves. Most often, certain apparel parts were beaded in the neck area, the lower sides (cuffs, hems), shoes or belts, beside other pendants. If found in the neck area (close to collars), they formed part of necklaces 


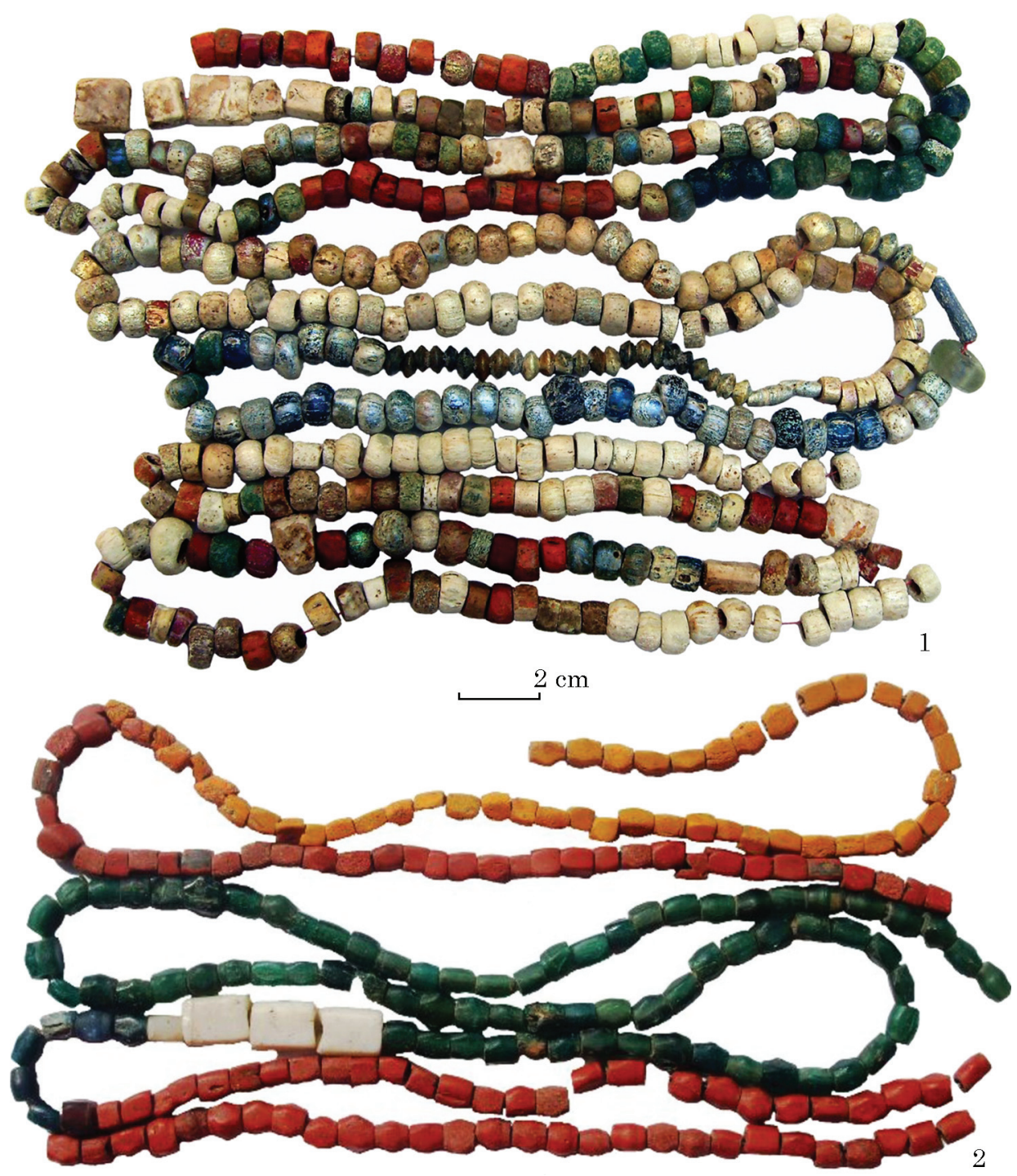

Fig. 9. Glass beads: 1 - Foeni-Cimitirul Ortodox, grave 14 (after Grumeza 2013); 2 - Giarmata - Site 10, grave 22 (after Grumeza 2014)

(fig. 8: 1). In certain graves, beads were discovered by wrists and ankles. Bead mixtures were varied from raw material, shape, colour, decoration or location standpoints. Good part of the graves were yet disturbed, bones did not survive in situ or did not preserve because of soil acidity. Therefore, in many cases, it is impossible to say where the beads originally lay or reconstruct how they were worn.

The anthropological-archaeological analyses made on various cemeteries ascribed to the Sarmatian culture in the Great Hungarian Plain show that garments embroidered with various beads (on dress hems or trousers) was specific to adult women and adolescents (Vörös 2003), and had a similar function with that of a wedding dress or a garment that marks the entry of women into adult society.

An example of glass beads worn as decoration on the lower sides of the coat/ dress was identified in grave 3 from the Hunedoara Timişană cemetery, where 592 beads (mainly in glass) were identified. The many specimens set on rows in the ankle area were beaded on the garment in 16 successive rows (fig. 7). Each row followed a certain chromatic and structural symmetry, with mostly alternating polyhedral and biconical beads:

- Row 1: 28 globular, green glass beads (Gr. I/ $\mathrm{D} / 1)$.

- Row 1, 2: 27 beads (Gr. I/B/1) of white glass; their surface preserves a dark-blue metal patina here and there.

- Row 3, 4: 39 polyhedral beads (Gr. V/A/2) of a highly friable stone, white; their surface still preserves a dark-blue metal patina here and there.

- Row 5-7: 54 biconical beads (Gr. II/B/1) glass, white; their surface still preserves a darkblue metal patina here and there.

- Row 8, 9: 39 polyhedral beads (Gr. V/A/2) of a highly friable stone, white; their surface still preserves a dark-blue metal patina here and there.

- Row 10-12: biconical beads (Gr. II/B/1) glass, white; their surface still preserves a darkblue metal patina here and there. 


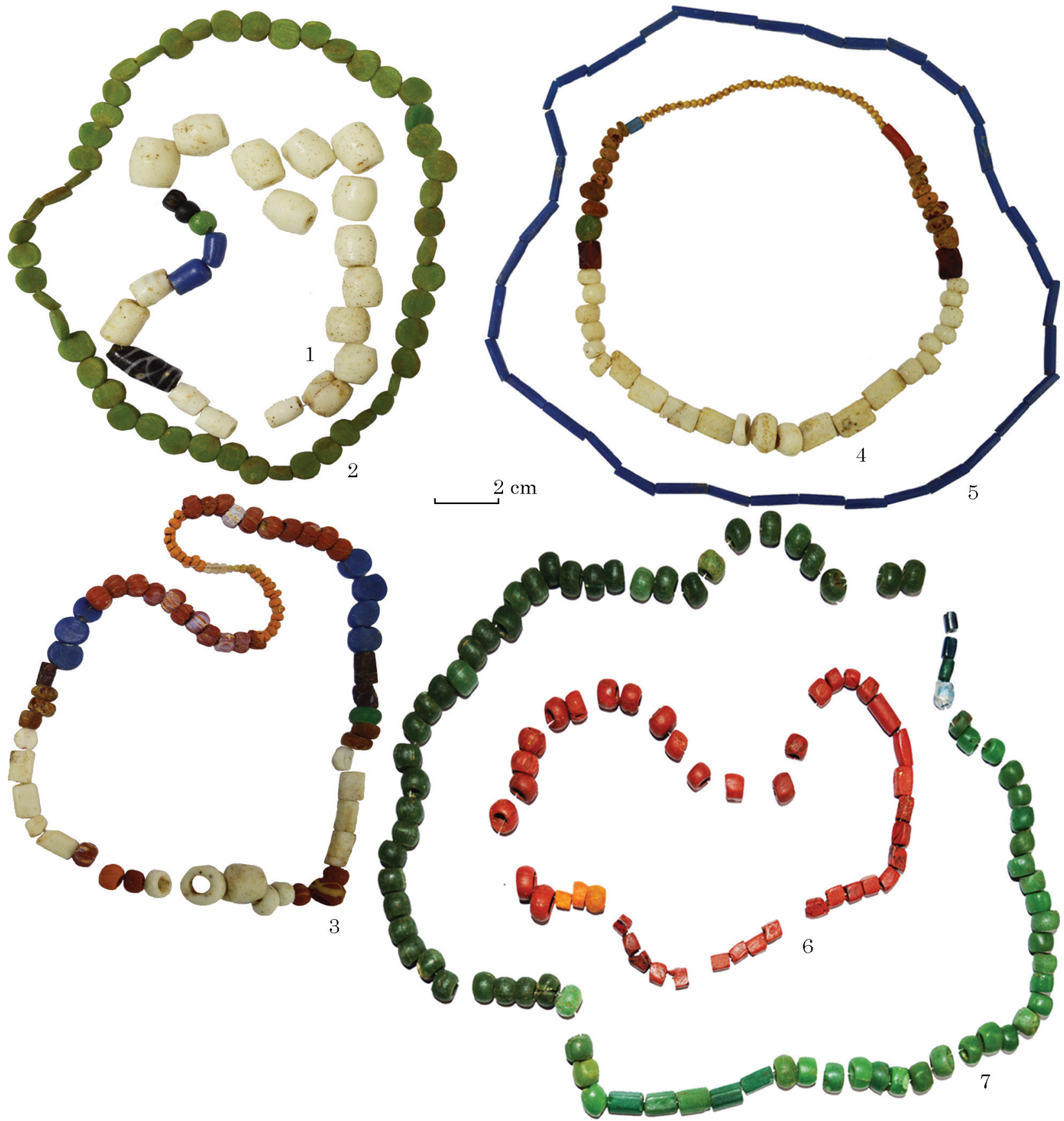

Fig. 10. Beads in graves at Hunedoara Timişană: 1-3 - G. 7; 4, 5- G. 8; 6, 7 - G. 9 (after Bârcă 2014a)

- Row 13: 22 polyhedral beads (Gr. V/A/2) of a highly friable stone, white; their surface still preserves a dark-blue metal patina here and there.

- Row 14, 15: 42 polyhedral chalcedony beads, flattened in profile, asymmetrically pierced.

- Row 16: symmetrical combinations of 27 minuscule glass beads covered with gold leaf (Gr. VII/A/1), in the shape of a simple sphere or formed of two, three or even four linked spheres and 5 disk beads, flattened (Gr. VIII/A/4), of porous, cherry glass (Grumeza, Rumegă-Irimuş, Barcă 2014, p. 122).

Similar setting was noted in certain Sarmatian graves from Hungary, like Kiskundorozsma-Sub- asa (grave 121) ${ }^{1}$, Site 26/ 78 (Bozsik 2003, p. 102, fig. $4,8,10,11)$. In the latter, the grave goods also included a bronze pyxis (Bozsik 2003, p. 102, fig. $7: 6 ; 8: 6$ ) identical with that in grave 3 from Hunedoara Timişană (Bârcă 2014a, p. 137, 149, pl. 7: 5; 72: 4; 2017, 109, 110, fig. 3: 3; 4: 2).

A chromatic order of the beads sewn onto apparel was also noticed in grave 9 at Hunedoara Timişană. By the deceased's feet were identified successive rows of globular beads (Gr. I/B), made predominantly of dull green, red and white glass. Each row maintained the same colour (Grumeza,

1. The place at Kiskundorozsma is located nearby Szeged (Hungary). 


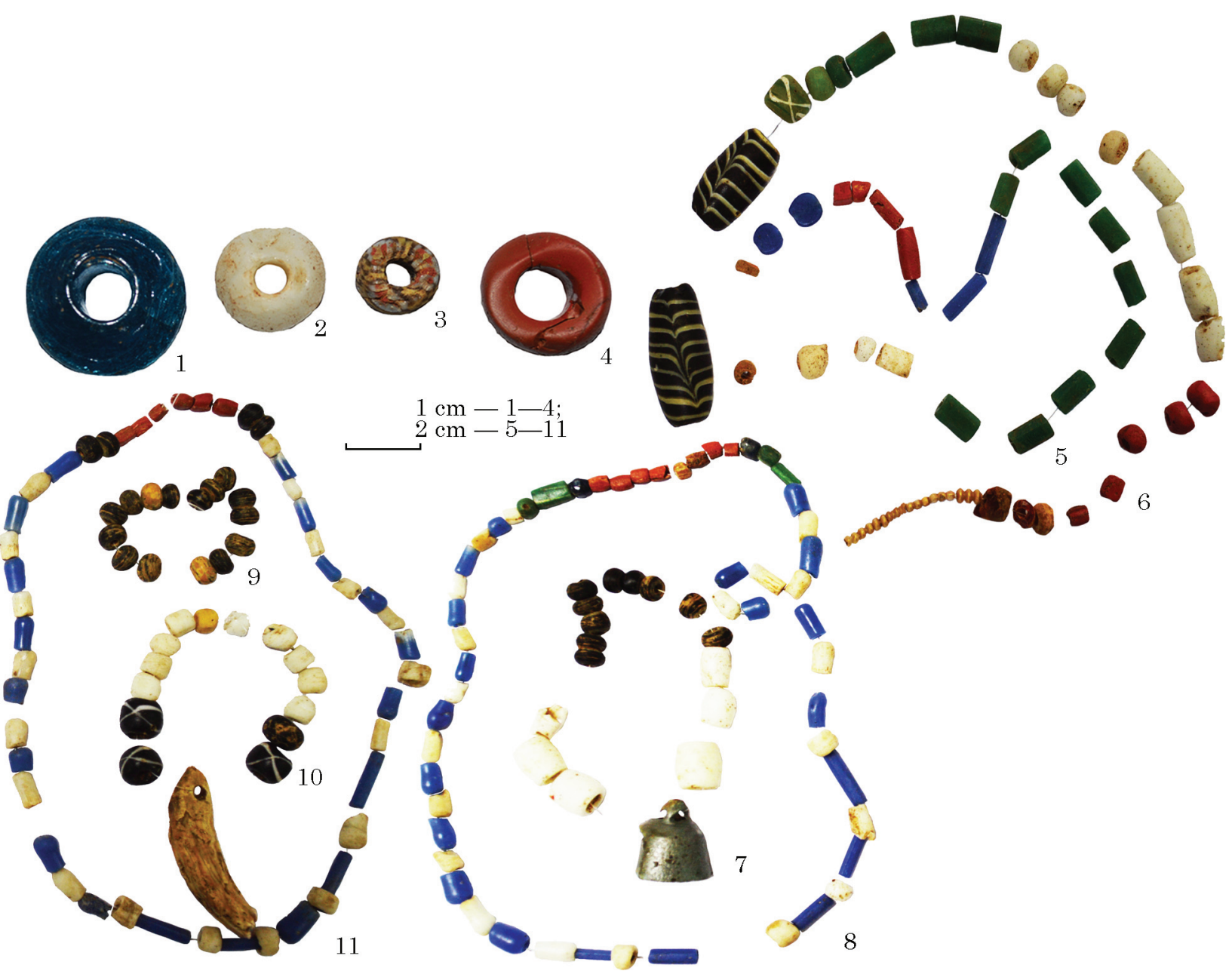

Fig. 11. Beads in graves at Hunedoara Timişană: $1-4$ - G. 2; 5, 6- G. 6; 7-11 — G. 15 (after Bârcă 2014a)

Rumegă-Irimuş, Barcă 2014, p. 123; Bârcă 2014a, p. 155,156 , pl. $26: 1 ; 61: 3)$.

On the territory south the Lower Mures river, similar bead setting was identified in other Sarmatian graves, for instance at Foeni-Cimitirul Ortodox, grave 2 . From this funerary complex come 398 specimens, the majority grouped in the lower part of the deceased's garments set symmetrically on one side, on 7 rows. The first row consisted of orange beads (Gr. I/B/5), the second — of red beads (Gr. I/B/6), the third - of white beads (Gr. I/B/1), the fourth - of green beads (Gr. I/B/3), the fifth — of red beads (Gr. I/B/6), the sixth — of green beads, all globular (Gr. I/B/3) and the seventh of carnelian prism beads (Grumeza 2011, p. 190).

The custom of embroidery-decorating garment hems with hundreds or even thousands of beads of various colours is recorded in the Sarmatian milieu of the Great Hungarian Plain as early as their settling of the area. The fashion peaks in the period after the Marcomannic wars, very likely influenced by the arrival in this area of new groups of Sarmatians by the end of the $2^{\text {nd }}-$ early $3^{\text {rd }}$ century AD (Kulcsár 1998, p. 48-51, 96, 97,112 ), when also emerge new funerary ritual and material culture elements. The hem-beading custom persisted in the $3^{\text {rd }}$ century $\mathrm{AD}$ and to a lesser extent in the $4^{\text {th }}$ century AD (Kulcsár 1998, p. 51, 97, 112). A careful analysis of the funerary finds shows the fashion spread in the Sarmatian environment of the Great Hungarian Plain, with the note that in the Upper Tisza area and the adjacent territories in the northern part of the Great Hungarian plain, the custom is rarely found (Kulcsár 1998, p. 51, 97, 112).

Beads embroidered on garments (the cuffs, collar and hem line/lower clothing parts) were also identified in a series of Sarmatian graves from certain cemeteries in the Lower Mureş river basin. For instance, glass beads discovered in the chest area, whose position evidences their beading onto clothes, come from the grave at Sânnicolau Mare-Selişte (G. 7/2005; Bejan, Măruia, Tănase 2011, p. 166), dated sometime by early / first two decades of the $2^{\text {nd }}$ century $\mathrm{AD}$, possibly after the events of AD 107-108 or early Hadrian's reign (Bârcă 2014a, p. 62; 2016a, p. 31, 32; Grumeza 2014, p. 142, 143). A similar embellishing manner of the female dress was documented in grave 2 at Dudeştii Vechi-Movila lui Dragomir, dated to the second half of the $4^{\text {th }}$ century $\mathrm{AD}$ or early $5^{\text {th }}$ century $\mathrm{AD}$. By both hands of the deceased were found 7 glass beads and 17 lime- 
stone beads, likely sewn onto the coat's sleeves, while by the feet - 380 limestone and 93 glass beads (Tănase 2004, p. 233-241).

A specificity of the Foeni-Cimitirul Ortodox cemetery is bead wearing in the form of bracelets - documented in graves $2,14,15$, possibly 8 . The bracelet in grave 2 was composed of glass beads (Gr. I/B, Gr. I/C, Gr. VI/A), a biconical limestone bead and an axe-shaped pendant (Grumeza 2011, p. 190, pl. IV: 1; 2014, 179, pl. 15: 2). These bracelets were most often composed of large beads, in limestone or glass, predominating polychrome beads in Groups IV and VI with floral decorations (millefiori) or inlaid stripes (fig. 8: 3). Such bracelets (made of multicoloured glass, poppy-head pendants, axed-shape pendants, bells, shells, limestone beads, etc.) are rarely documented in the Sarmatian graves of the Great Hungarian Plain and are a specificity of the richly furnished female graves (see the case of Abony 39 cemetery, graves 95 and 71b; Gulyás 2011).

Beads - as earring parts - were documented in grave 14 from the Hunedoara Timişană cemetery. The earrings were made of a silver thread, with an extremity bent in the shape of a loop wound onto the specimen's body and the other extremity bent as a hook. One of the earrings had attached to its body two slightly translucent dark-blue biconical glass (Gr. VI/A/2; Bârcă 2014a, p. 158, pl. 35: 2; 73: 6. To date, this form is unique in the Sarmatian world (fig. 8: 2). On the territory of Banat are known earring variations completed with carnelian beads and / or silver pendants, yet in other forms, found in graves 8, 9 and 14 in the Vršac-Dvorište Eparhije Banatska cemetery (Barački 1961, pl. VII: 8, 9; XI: 1, 2). Earrings with silver link, mixed with carnelian beads emerge in a series of Sarmatian graves from the cemeteries on the territory of Hungary, like those at Endrőd-Kocsorhegy (Juhász 1978, p. 107, 114, pl. II: 9, 10), Madaras-Halmok (Kóhegyi, Vörös 2011, p. 263, 264, fig. 256: 4, pl. 64: 4, 5), SzentesZalota (Nagy 1997, p. 69, pl. 13: 1), Zsámbok (Párducz 1950, pl. LXXII: 1, 2) and Szeged-Öthalom (Párducz 1958-1959, p. 98, 99, pl. XXVII: 11, 12) etc.

Another bead wearing manner was documented in grave 7 at Hunedoara Timişană. In this case, beads were likely part of a fabric braid fastened centrally by a metallic ring (fig. $7: 2$ ). The objects were positioned to the left of the deceased, on a north-south axis. Similar belts likely existed in graves 3, 6 and 15 as well. These were worn on the left side, completed with various pendants, bucket-pendants, pyxides, bells etc., hung by strings. Such dress objects were discovered in numerous female graves in the Szeged-Csongrádi út cemetery, graves 14, 19, 24, 25 (Vörös 1981, pl. 2, 4, 8, 9). The presence of belts / cords is firstly marked by the find of a link (used to knot the cordon) and the stringing, on the left side, of beads, bronze bells, bone pendants, but also of knives or other objects that could be hung on the belt (Vörös 1981, p. 132).

From above mentioned examples, we note that beads were very important dress objects in the Sarmatian female costume. They did not have only an aesthetic value, but also marked the status of women in society, either adolescent or adult. Furthermore, graves with numerous beads were also richly furnished, thus providing important clues for identifying the Sarmatian female elite from the area south the Lower Mures river.

Subsequent to the analysis of the beads identified in the Sarmatian cemeteries from southwestern Romania (especially the Foeni-Cimitirul Ortodox, Hunedoara Timişană and Giarmata Sit 10 burial grounds), it may be concluded that most opaque and translucent monochrome glass beads were most likely crafted in the Tibiscum workshops, contemporary with the three cemeteries and making similar glass beads (identical in type, colour and size). A similar origin may be invoked for the majority of polychrome beads (groups I-VI, VIII). The position of the beads when discovered in the graves from south-western Romania - indicates that functionally, we are dealing with the same fashion documented in the most part of the Great Hungarian Plain after the Marcomannic wars. Many glass beads originated from the Sarmatian cemeteries in the area between the Lower Mureş river, the Tisza and the Danube, are dating to the period comprised between the end of the $2^{\text {nd }}$ century and the last third of the $3^{\text {rd }}$ century $\mathrm{AD}$. According to the internal chronology of the three above mentioned Sarmatian cemeteries, the bead types (and type mixtures) are specific to this period.

Acknowledgment. This work was supported by a grant of the Ministry of Research and Innovation, CNCS - UEFISCDI, project number PNIII-P1-1.1-PD-2016-0223, within PNCDI III.

\section{REFERENCES}

Alekseeva, E. M. 1975. Antichnye busy Severnogo Prichernomorya. Arkheologiya SSSR, Svod arkheologicheskikh istochnikov, G 1-12. Moskva: Nauka.

Alekseeva, E. M. 1978. Antichnye busy Severnogo Prichernomorya. Arkheologiya SSSR, Svod arkheologicheskikh istochnikov, G 1-12. Moskva: Nauka.

Alekseeva, E. M. 1982. Antichnye busy Severnogo Prichernomorya. Arkheologiya SSSR, Svod arkheologicheskikh istochnikov, G 1-12. Moskva: Nauka.

Antonaras, A. Ch. 2017. Glassware and Glassworking in Thessaloniki $1^{\text {st }}$ Century $B C-6^{\text {th }}$ Century $A D$. Archaeopress Roman Archaeology, 27. Oxford: Archaeopress.

Barački, St. 1961. Sarmatskie nalazi iz Vršca. Rad Vojvođanskih muzeja, 10, p. 117-143.

Batistić-Popadić, D. 1984-1985. Sarmatska nekropola Vojlovica-Pančevo. Rad Vojvođanskih muzeja, 29, p. 59-83.

Bârcă, V. 2014a. Sarmatian Vestiges Discovered South of the Lower Mures River. The Graves from Hunedoara Timişană and Arad. Cluj-Napoca: Mega. 
Bârcă, V. 2014b. Returned foot exterior chord brooches made of a single metal piece (Type Almgren 158) recently discovered in the Western Plain of Romania. Notes on origin and chronology. Journal of Ancient History and Archaeology, 1, 2, p. 21-39. DOI: $10.14795 /$ j.v1i2.50.

Bârcă, V. 2016a. Disc brooches of box / capsule type (Dosenfibel / Kapselfibel) in the Sarmatian environment of the Great Hungarian Plain. A few notes on their dating and origin. In: Bârcă, V. (ed.). Orbis Romanus and Barbaricum. The Barbarians around the Province of Dacia and Their Relations with the Roman Empire. Cluj-Napoca: Mega, p. 251-282.

Bârcă, V. 2016b. The dating of the Sarmatian grave at Sânnicolau Mare - Selişte (Timiş county, Romania) and the issue of the early Sarmatian entry and settlement of the Pannonian Plain. Ephemeris Napocensis, XXVI, p. 7-66.

Bârcă, V. 2017. Notes on the metal pyxides recently discovered in the Sarmatian environment south the Lower Mureş River. Plural. History-Culture-Society, 5, 2, p. 101-123.

Bârcă, V., Ursuțiu, A., Cociş, S. I., Stăncescu, R. E., Țuțuianu, C. D., Irimuş, L., Cociş, Al., Sălcudean, C., Bondric, A., Brehuescu, Al. 2011. Hunedoara Timişană, com. Şagu, jud. Arad, Punct: Autostrada AradTimişoara, tronson Arad-Seceani, km 23+170-23+690 (siturile B0_7-B0_8). Cronica cercetărilor arheologice din România: campania 2010, p. 187-192.

Bârcă, V., Grumeza, L. 2014. Sarmatian Burials in Coffins and Funerary Timber Features Recently Discovered in the Western Plain of Romania. Ephemeris Napocensis, XXIV, p. 157-194.

Bejan, A., Măruia, L., Tănase, D. 2011. Un mormânt cu podoabe de aur din epoca sarmatică timpurie descoperit la Sânnicolau Mare - Selişte (Timiş county). Analele Banatului, XIX, p. 161-180.

Benea, D. 1996. Dacia sud-vestică în secolele IIIIV. Timişoara: Vest.

Benea, D. 2004. Die Romischen Perlenwerkstaetten aus Tibiscum / Atelierele romane de mărgele de la Tibiscum. Timisoara: Excelsior Art.

Benea, D. 2008. Accesorii vestimentare. Mărgelele (I). Între import şi producție internă. Bibliotheca Historica et Archaeologica Universitatis Timisiensis, X: Studii de istorie economică a Daciei romane, p. 134166.

Bozsik, K. 2003. Szarmata sírok a Kiskundorozsmasubasai 26/78. lelóhelyen. In: Szalontai, Cs. (ed.). Útonútfélen. Múzeumi kutatások az M5 autópálya nyomvonalán. Szeged: Móra Ferenc múzeum, p. 97-106.

Daicoviciu, C. 1942. Bănatul şi iazygii. Apulum, 1 (1939-1942), p. 98-109.

Grumeza, L. 2011. The Sarmatian Necropolis from Foeni (Timiş County). Analele Banatului, XIX, p. 181-205.

Grumeza, L. 2013. Typology and Chronology of the Beads Found within the Foeni Sarmatian Necropolis. Tibiscum, 3, p. 245-260.

Grumeza, L. 2014. Sarmatian Cemeteries from Banat (Late $1^{\text {st }}$ - Early $5^{\text {th }}$ Centuries $\left.A D\right)$. Cluj-Napoca: Mega.

Grumeza, L. 2018. Fashion by rituals: rosette glass beads found in Sarmatian and Sântana de MureşChernyakhov cultures $\left(1^{\text {st }} \mathrm{c} . \mathrm{BC}-4^{\text {th }}\right.$ c. AD). Arheologia Moldovei, XLI, p. 193-218.

Grumeza, L. 2019. Corpus der römischen Funde im europäischen Barbaricum. Rumänien. 1: Kreis Arad. Cluj-Napoca: Mega.

Grumeza, L. 2020. The More Colourful, the Better! Polychrome Glass Beads of the $2^{\text {nd }}-4^{\text {th }}$ Century Cem- eteries in Banat. In: Mărgărit, M., Boroneanț, A. (eds.). Beauty and the eye of the beholder. Personal adornments across the millennia. Târgovişte: Cetatea de Scaun, p. 437-445.

Grumeza, L. Rumegă-Irimuş, L., Bârcă, V. 2014. Beads. In: Bârcă, V. Sarmatian Vestiges Discovered South of the Lower Mures River. The Graves from Hunedoara Timişană and Arad. Cluj-Napoca: Mega, p. $120-133$.

Gulyás, G. 2011. Szarmata temetkezések Abony és Cegléd környékén. Studia Comitatensia, 31, p. 125253.

Juhász, I. 1978. Szarmata temető Endrődön, A Békés Megyei Múzeumok Közleményei, 5, p. 87-114.

Kóhegyi, M., Vörös, G. 2011. Madaras - Halmok, Kr. U. 2-5. Századi szarmata temetô. Szegedi: Tudományegyetem Régészeti Tanszékéról.

Kulcsár, V. 1998. A kárpát-medencei szarmaták temetkezési szokásai. Aszyd: Város Önkormányzata.

Nagy, M. 1997. Szentes és környéke az 1—6. században. Történeti vázlat és régészeti lelóhelykataszter. Studia Archaeologica. A Móra Ferenc Múzeum Evkönyve, III, p. 39-95.

Párducz, M. 1950. A szarmatakor emlékei Magyarországon. III. Archaeologia Hungarica, XXX. Budapest: Budapest Akadémiai Kiado.

Párducz, M. 1958-1959. Hunkori Szarmata temető Szeged-Öthalmon. A Móra Ferenc Múzeum Evkönyve, p. 71-99.

Párducz, M. 1960. Koraszarmata sírok Csanyteleken. Folia Archaeologica, XII, p. 71-74.

Simonenko, A. V. 1993. Sarmatian tribes of the Great Hungarian Plain and the North Pontic region. Problem of migration. Specimina Nova, IX, p. 59-64.

Simonenko, A. V. 2001. On the tribal structure of some migrations waves of Sarmatians to the Carpathian Basin. In: International Connections of the Barbarians of the Carpathian Basin in the $1^{\text {st }}-5^{\text {th }}$ centuries A.D. Aszyd-Nyíregyháza: Osváth Gedeon Museum Foundation, Jósa András Múzeum, p. 117-124.

Skripkin, A. S. 1990. Aziatskaya Sarmatiya. Problemy khronologii i ee istoricheskij aspekt. Saratov: SGU.

Tănase, D. 2004. Două morminte din secolele IVV p. Chr. descoperite la Dudeştii Vechi (jud. Timiş). Analele Banatului, X-XI, 1, p. 233-244.

Tempelmann-Maczyńska, M. 1985. Die Perlen der römischen Kaiserzeit und der frühen Phase der Völkerwanderungszeit im mitteleuropäischen Barbaricum. Mainz am Rhein: Philipp von Zabern.

Vörös, G. 1981. Adatok a szarmatakori nôi viselethez. Communicationes Archaeologicae Hungaricae, p. 121-135.

\section{Grumeza, V. Bârcă}

\section{GLASS BEADS DISCOVERED IN THE SARMATIAN CEMETERIES FROM SOUTH-WESTERN ROMANIA}

This paper analyses the glass beads discovered in the cemeteries attributed to the Sarmatian culture from South-Western Romania, especially Foeni-Cimitirul Ortodox (Timiş county), Giarmata - Sit 10 (Timiş county) and Hunedoara Timişană (Arad county). Beads are the most numerous objects identified among grave goods (over 14000 specimens), being present in 43 cemeteries dated between the $2^{\text {nd }}$ and the $4^{\text {th }}$ century AD. Nevertheless, their number differs from one burial ground to another, according to the peculiarities 
of each site, distance from the limes, quantity of Roman imports within the burials, resources available to respective communities, the chronological period to which the burial / cemetery belongs to or the number of female graves in each cemetery.

Typologically, we identified 9 main types of monochrome glass beads and 8 types of polychrome glass beads (each with variations, different colours and forms). The studies discussing beads discovered in the European Barbaricum use the classification suggested by M. Tempelmann-Mączyńska (for the central and north European Barbaricum) and E. M. Alekseeva (for the north of the Black Sea). Unfortunately, these typologies may not be adopted in our case, since beads discovered in Sarmatian funerary sites and features from the Great Hungarian Plain (and implicitly today's western Romania) are typological series different than those from the centre, north and east of Europe. Furthermore, the workshops making and then distributing the beads here are known (e. g. Tibiscum in the southeastern part of Roman Dacia). Therefore, we drafted our own typology, adapted to the archaeological realities of the area.

Most often, beads were sewn onto apparel (the same fashion is documented in the most part of the Great Hungarian Plain after the Marcomannic wars). We note that beads were very important dress objects in the female costume. They did not have only an aesthetic value, but also marked the status of women in society, either adolescent or adult. Furthermore, graves with numerous beads were also richly furnished, thus providing important clues for identifying the Sarmatian female elite from the area south the Lower Mures river. Thus, the beads are highly important for discussions concerning the fashion of the time, trading relations and Roman-Barbarian contacts and connections.

Keywords: glass beads, Sarmatians, cemeteries, Roman-provincial workshops, Western Plain of Romania, Banat region.

\section{Л. Грумеза, В. Бирке}

\section{СКЛЯНІ НАМИСТИНИ 3 САРМАТСЫКИХ МОГИЛЬНИКІВ ПІВДЕННО-ЗАХІДНОЇ РУМУНІЇ}

У цій роботі проаналізовано скляні намистини, виявлені на могильниках сарматської культури 3 Південно-Західної Румунії, особливо Фоень-Чімітірул Ортодокс (округ Тіміш), Джармата-Сіт 10 (округ Тіміш) та Хунедоара Тімішане (округ Арад). Намистини - найчисленніші предмети, виявлені серед поховального начиння (понад 14000 екземплярів), присутні на 43 могильниках, що датуються між II та IV ст. н. е. Проте їх кількість відрізняеться від одного могильника до іншого залежно від особливостей кожної ділянки, відстані від лімесу, кількості римського імпорту в похованнях, ресурсів, доступних відповідним громадам, хронологічного періоду, до яко- го належить поховання / могильник або кількість жіночих могил на кожному могильнику.

Типологічно виокремлено 9 основних типів монохромних скляних намистин та 8 типів поліхромних скляних намистин (кожен із варіаціями, різними кольорами та фрормами). Дослідники намистини, виявлених в европейському Барбарикумі, використовують класифрікацію, запропоновану М. Темпельманн-Мончиньською (для центральної та північно-европейської Барварикума) та Е. М. Алексеєвою (для античного Причорномор'я). На жаль, у нашому випадку ці типології не можуть бути прийнятими, оскільки намистини, виявлені в сарматських похованнях Великої угорської рівнини (i, очевидно, сьогоднішньої західної Румунії), е типологічно відмінними від тих, що знайдені в центрі, на півночі та сході Європи. Крім того, тут відомі майстерні з виготовлення та розповсюдження намистин (наприклад, Тібіскум у південно-східній частині Римської Дакії). Тому ми склали власну типологію, адаптовану до археологічних реалій району.

Найчастіше намистини пришивали до одягу (такий спосіб зафіксовано на більшій частині Великої Угорської рівнини після Маркоманських війн). Зазначимо, що намистини були дуже важливими предметами сукні в жіночому костюмі. Вони не мали лише естетичної цінності, але також відзначали статус жінок у суспільстві, як підлітків, так і дорослих. Крім того, могили 3 численними намистинами містили також численне начиння, що надало важливі ознаки для ідентифрікації сарматської жіночої еліти 3 району на південь від річки Нижній Муреш. Таким чином, намистини надзвичайно важливі для досліджень тогочасної моди, торгових відносин та римсько-варварських контактів та зв'язків.

Ключові слова: скляні намистини, сармати, кладовища, римсько-провінщійні майстерні, Західна рівнина Румунії, область Банат.

Одержано 25.04.2020

БИРКЕ Віталіє, доктор археології, старший науковий співробітник, Інститут археології та мистецтвознавства Клуж-Напока, Румунська академія наук, адресавул. Міхая Когелнічану, 12-14, Клуж-Напока, 400084, Румунія.

BÂRCÂ Vitalie, Dr., Senior Fellow II, the Romanian Academy, Institute of Archaeology and Art History of Cluj-Napoca, Mihail Kogălniceanu St., 12-14, ClujNapoca, 400084, Romania.

ORCID: 0000-0003-3078-374X, e-mail: vitalie_barca@ yahoo.com.

ГРУМЕЗА Лавінія, доктор археології, науковий співробітник, Археологічний інститут Яси, Румунська академія наук, вул. Кодреску, 6, павільон Н, Яси 700479, Румунія.

GRUMEZA Lavinia, Dr., Fellow, the Romanian Academy, Archaeology Institute of Iaşi, Codrescu St., 6, Pavilion H, Iași, 700479, Romania.

ORCID: 0000-0001-6076-5708, e-mail: lavinia_grumeza@yahoo.com. 